DOI: $10.52837 / 27382702-2021-34.1-9$

\title{
COMPUTER MODELING IN ARCHAEOLOGY: THE CASE OF BRONZE AND IRON AGE MONUMENTAL CONSTRUCTIONS OF ARMENIA*
}

\author{
Hayk Avetisyan, Artak Gnuni, Levon Mkrtchyan,
} Arsen Bobokhyan

\begin{abstract}
The given contribution is devoted to the problem of computer modeling in archaeology. The territory of the Republic of Armenia is chosen as a target zone for investigations, which is considered in the context of historical and cultural developments of the neighboring countries. The chronological range of the given study is the Bronze and Iron Ages (3rd-1st millennia BC). The principles of computer modeling are applicable to the investigation of monumental architecture (fortifications, towers, cairns, kites, kurgans, dolmens), aiming at reconstructing both the complexes of the monuments and the historical landscape.
\end{abstract}

Keywords: Archaeology, Computer, GIS system, Bronze Age, Iron Age, Armenia, "Cyclopean" constructions, Artsakh, Syunik.

\section{The statement of the issue and the perspectives of the investigation}

This research is dedicated to the study of the traditions of the earliest monumental architecture in the territory of the Republic of Armenia, which is considered in the context of similar constructions in neighboring regions. In chronological sense the research focuses on the Bronze and Iron Ages (from $3^{\text {rd }}$ to the beginning of the $1^{\text {st }}$ millennia $B C$ ), which reflects the Kura-Araxes, Trialeti as well as the Lchashen-Metsamor cultural traditions.

The choice of the research topic is conditioned by the actuality of the scientific issue. Particularly, this study implies a theoretical, historicalarchaeological and fieldwork investigation of the monumental architecture and

\footnotetext{
* The article was submitted on May 8, 2021: The article was reviewed on May 20, 2021.
} 
then, as a result of it, a practical modeling and reconstruction of the relevant constructions and landscapes, which became a dominant direction in the current archaeological investigations. The actuality of the project specifically for Armenia is conditioned by the fact that Armenian archaeological heritage has never been systematically studied from the viewpoint of computer modeling. Thus, the supposed topic acquires both scientific-academic and practical significance in the context of publicizing archaeological knowledge and museification of the results.

The study of the monumental architecture is one of the important issues of modern archaeology, allowing to accertain numerous problems connected to the social-economic and spiritual-cultural developments of ancient societies. Specifically in our case, the appearance of similar structures is considered in a contact zone of the ancient world, where the interactions between the farming civilizations of the Near East with the Eurasian steppe dwellers took place. The earliest monumental constructions of Armenia are mentioned in the travel notes of previous centuries alluding to their richness ${ }^{1}$. In particular, Tavernier mentiones a powerful fortress on the slopes of Ararat ${ }^{2}$. Taghiadian and Parrot were the first who described the monumental cemeteries on the top of $L$. Ararat $^{3}$. Haxthausen describes monumental structures (alignment, kurgans, and tower) not far from Yerevan: perhaps in Yeghvard. He was one of the first to use the term cyclopean architecture ${ }^{4}$. Berger mentions the importance of investigation of Syunik and Vayots Dzor alignments ${ }^{5}$. But the scientific study of monumental achitecture began only at the end of the 19th century ${ }^{6}$. During the past century numerous papers appeared, where both the separate units ${ }^{7}$

${ }^{1}$ Srvandzteants 1862-1863: 88.

2 Tavernier 1678: 16-20.

${ }^{3}$ Parrot 1990: 97-99, Taghiadian 1846: 104.

${ }^{4}$ Haxthausen 1857: 215-217.

${ }^{5}$ Berger 1874: 43

${ }^{6}$ Ivanovski 1911; Atrpet 1914; Kalantar 1925; Barkhudaryan 1935; Piotrovski, Gyuzalyan 1933; Piotrovski 1949.

${ }^{7}$ Khanzadyan 1969, 1973, 1979; Khachatryan 1975; Sardaryan 1967, 2004; Simonyan 2013. 
and the subzones of their spreading ${ }^{8}$ were discussed. The present literature creates opportunities for syntheses ${ }^{9}$. At the same time, essential acquisitions were attested in the study of monumental constructions of the Caucasus ${ }^{10}$, and especially that of the fortification systems.

During the last years, an attempt was made to summarize the available material on the one hand, and on the other hand, to put new materials into circulation. Significantly, since 1996 several dozens of monumental constructions (fortresses, towers, kites, cairns, alignments, cromlechs) were investigated in the territory of Armenia and Artsakh, particularly in the provinces of Aragatsotn, Shirak, Armavir, Vayots Dzor, Syunik, as well as Karvachar and Kashatagh regions. Separate cells of these constructions have been distinguished in different regions of Armenia: investigations allow us to consider several local-chronological versions. Aerial photographs of some monuments were realized, particularly in the southern regions of the Republic of Armenia and Artsakh. Preliminary mapping of the corresponding monuments of Armenia was realized by GIS system. The results of the mentioned investigations were partially published ${ }^{11}$.

In spite of all this, numerous issues connected to the history of development of monumental structures still remain unsolved. Among them are:

The issue of origin of monumental constructions.

The issue of appearance, as well as socio-economic and political significance of the so-called "Cyclopean" constructions.

The issue of using various construction methods and techniques in different regions.

The extravert and intravert building of settlement cells, formation of separate fortified cells and their possible connections.

8 Mikaelyan 1968; Khachatryan 1975; Esayan 1976; Biscione et al. 2002; Badalyan, Avetisyan 2007; Smith et al. 2009; Sanamyan 2010.

${ }^{9}$ Areshyan et al. 1996; Kushnareva 1996.

${ }^{10}$ Rasulogli 1993; Narimanashvili 2009, Reinhold 2009.

${ }^{11}$ Avetisyan et al. 2014; Avetisyan et al. 2015a,b; Avetisyan et al. 2016; Gnuni 2010; Gnuni, Khachatryan 2010; Gnuni et al. 2011; Gharibyan et al. 2011; Sargsyan et al. 2014; Avetisyan 2012. 
The issue of relations of monumental structures with the socio-economic and spiritual-cultic parts.

Ancient routes.

The issue of the relations of monumental constructions in different regions and their historical-cultural subtext.

Based on the above mentioned points the purposes of this investigation are:

To introduce the peculiarities of the monumental architecture of the Bronze and Iron Age Armenia in the context of synchronous Near Eastern and Caucasian regions, and to explain the paradigms of the existence or the absence of monumentalism in mountainous zones.

To separate and describe the types of monumental constructions in spatial and chronological context.

To consider the sphere of spreading of "Cyclopean" constructions, finding out the reasons of the origin of monumental way of thinking ${ }^{12}$.

To describe the landscapes typical to the "Cyclopean" constructions, their natural and anthropogenic elements, comparing them with the examples of other regions, as well as, in accordance with this, and to map the fortresses and fortified settlements by using the GIS system.

To consider the monumental way of thinking in the context of historical and cultural relations and to visualize all this by the means of modern computer technologies.

The main purpose of such investigation is the modeling of the materials obtained by the archaeological research through three-dimensional images and videos. The need for modeling arises when the study of the object itself is difficult ${ }^{13}$. The graphic modeling of the archaeological objects aims at presenting to the public the history and the "trajectory" of development of the studied area and its features in a visible way ${ }^{14}$. Reconstruction and visualization of the historical units are perspective in the museum work, for

\footnotetext{
12 For theoretical questions cf. Trigger 1990.

${ }^{13}$ Chernosvitov 1989: 23.

${ }^{14}$ Chernosvitov 1989: 23.
} 
the development of tourism has a practical significance in the didacticenlightenment field from the point of view of preservation of historical values and their dissemination. Important are in this context the graphic presentation of archaeological information facilitates, the process of getting acquainted with cultural values, giving a person the opportunity to acquire knowledge through bright. This is a modern method of being present in a virtual information system. Within this framework works are carried out in different regions of Armenia: Armavir (Haytagh, Arshaluys, Shresh Blur-Norakert), Aragatsotn (Ujan, Avan, Kosh, Voskehat, Shamiram, Parpi, Mughni, Lazaravan, Aragatsavan, Arteni), Kotayk (Kaputan, Oshakan, Aramus, Kamaris), Vayots Dzor (Spitak Kar, Kapuyt, Gomk), Syunik (Harzhis, Khoznavar) and Gegharkunik (Sotk, Artanish). The modeling of monumental architecture is a promising field of work, as it implies the possibility of large-scale reconstructions.

\section{Working methods}

In order to realize the mentioned steps the following methods are used:

The first stage of the study is the formulation of the problem and the study of the sources ${ }^{15}$, primarily cartographic ones. In this context, the method of studying the "Google earth" system with three-dimensional space photos is applicable. Suspicious points are compared with 1:25 000 and 1:50 000 topographic maps, supplemented by the information contained in them. The opposite process also takes place: the separate cemeteries, ruins, which are mostly abandoned villages or castles, are combined with space photos ${ }^{16}$.

Field surveys, documentation of monuments, if necessary, test trenchings, on the basis of which the constructive features of the structures and their components are to be theoretically defined.

Aerial photography of the monuments and their measurement. This method allows not only fixing the modern landscape and outlining the

\footnotetext{
${ }^{15}$ Cf. Kvirkveliya, Radilovski 1994: 10.

${ }^{16}$ Sargsyan et al. 2014: 150.
} 
boundaries of large archaeological sites, but also it allows noticing the ancient riverbeds and irrigation systems ${ }^{17}$.

Classification, dating, drawing of the investigated objects.

Mapping of monuments by using GIS system with definition of landscape peculiarities ${ }^{18}$. A map is a mean of establishing patterns of distribution and relationship of archaeological complexes. In addition, archaeological maps are pivotal in solving issues of paleoecology and the relationship between humans and the environment ${ }^{19}$.

Preparing of available data for modeling.

As a result of working with the materials, renderings of models of constructions is created with different angles, from outside to inside: For getting 3D models Agisoft PhotoScan and Pix4Dmapper is applied, maps of altitudes are realized through Global Mapper, mapping and data base through QGIS.

Based on the final processing of materials, appropriate three-dimensional models and videos are created.

Existing revisions are used in the final publications, enriching the scientific text, as well as in popularization of the material acquired.

\section{Conclusion}

Digital archaeology is a popular direction in today's world and such studies are being done in Armenia as well. However, these researches have never been systematic. The mentioned cooperation and the combination of the joint results increases the efficiency of research and representation, as well as creates a basis for applying the obtained images not only for scientific, but also for educational purposes. The results can be used to arouse interest among the public.

The result of the digital modeling of the archaeological monuments of Armenia will be composed of the catalogue of the monumental constructions of Armenia and a corresponding distribution map, modeling of the target

\footnotetext{
${ }^{17}$ Doyel 1979: 15-17, 47-63; Avetisyan et al. 2019: 97.

${ }^{18}$ Conolly, Lake 2006; Avetisyan et al. 2019: 97-98.

${ }^{19}$ Lbova 1989: 181.
} 
monuments and their landscapes and reconstruction of ancient routes. A work which aims at reconstructing the features of monumental constructions and introducing them in their landscape, historical and cultural context, while making the data available for the public by computer modeling has a great innovative potential.

\section{BIBLIOGRAPHY}

Arešyan G., Hovhannisyan K., Kafadaryan K. (ed.) 1996: Haykakan čartarapetut'yan patmut'yun, (History of Armenian architecture), vol. 1, Yerevan (in Armenian).

Atrpet 1914: Šhiraki ačkatarean (kiklopyan) amrotsneri, Azgagrakan Handes (Cyclopean fortresses of Širak, Ethnographical Journal) 25, 165-188 (in Armenian). Avetisyan H. 2012: Aramus, Aleppo.

Avetisyan H., Bobokhyan A. Gnuni A. 2014: Uğegc'ayin hnagitakan aytselut'yun patmakan Syunik'i Vayots Dzori marz. Patmut'yun ev Mshakuyt' (Archaeological surveys in the region of Vayots Dzor of historical Syunik), History and Culture, Yerevan, 424-437 (in Armenian).

Avetisyan H., Bobokhyan A., Gnuni A., Sargsyan G. 2015a: Bronz-erkat'edaryan Syunik'i srbazan landšafti (The sacred landscape of the Bronze-Iron Age Syunik), Yerevan (in Armenian).

Avetisyan H., Bobokhyan A. Gnuni A. 2015b: Ditoğut'yunner Syunik'um m.t'.a. III-I haz. c'isakan landšafti dzevavorman veraberyal. Antar C'nndots. (Remarks towards the formation of ritual landscape in Syunik in the III-I millennium BC, Forest of Birth), Yerevan, 64-79 (in Armenian).

Avetisyan H., Bobokhyan A. Gnuni A. Danielyan H. 2016: Landšafti modelavorumi vağ hasarakut'yunnerum ev nra usumnasirut'yan ardi himnakhndirnerə. Hayastani hnamardabanut'yan ev hnažoğovrdagrut'yan hartser, Mijazgayin gitažoğovi (Modeling of landscape in early societies and the modern problems of its study, Issues of Archaeo-Anthropology and Demography of Armenia, Theses of International Scientific Conference), Yerevan, 5-8 (in Armenian).

Avetisyan H., Bobokhyan A., Gnuni A., Mkrtchyan L., Avetisyan N. 2019: Landšafti hnagitakan usumnasirut'yan arandznahatkut'yunnerə, Patmut'yun ev Mšakuyt‘ (Features of Archaeological Study of Landscape), History and Culure 1, 95-106 (in Armenian). 
Badalyan R., Avetisyan P. 2007: Bronze and Early Iron Age archaeological sites in Armenia. I, Mt. Aragats and Surrounding Region, Oxford.

Barkhudaryan S. 1935: Khorhrdayin Hayastani nyut'akan kulturayi hušardzannerə (Monuments of material culture of Soviet Armenia), Yerevan (in Armenian).

Berger S. 1874: Kavkaz v arkheologičeskom otnošenii (The Caucasus in archaeological terms), Tiflis (in Russian).

Biscione R., Hmayakyan S., Parmegiani N. 2002: The north-eastern frontier: Urartians and Non-Urartians in the Sevan Lake Basin, I. The southern Shores, Documenta Asiana VII, Roma.

Chernosvitov P. 1989: Metodičeskie priyomi modelirovaniya, rekonstruktsiy v arkheologii, Metodičeskiye problemi rekonstruktskiy $\mathrm{v}$ arkheologiy i paleoekologii. (sbornik trudov). (Methodological techniques for modeling, reconstructions in archaeology. Methodological problems of reconstructions in archaeology and paleoecology (Collection of scientific papers), Novosibirsk, 16-32 (in Russian).

Conolly J., Lake M. 2006: Geographical Information Systems in Archaeology, Cambridge.

Esayan S. 1976: Drevnyaya kultura plemyon Severo-Vostočnoy Armenii (Ancient culture of tribes of north-eastern Armenia), Yerevan (in Russian).

Gharibyan I., Simonyan H., Gnuni A., Ayvazyan E., Kamalyan E., Khačatryan G. 2011: Syunik'yan norahaytumner, Hušardzan (Discoveries in Syunik, Hušardzan) 7 , 129-142 (in Armenian).

Gnuni A. 2010: Hayastanum k'ağak'agoyatsman himnahartsi šurj (Towards the problem of the origin of cities in Armenia), Vem 6, 89-111 (in Armenian).

Gnuni A., Khačatryan G. 2010: Ağavnoi vernahosank'i norahayt hušardzannrə, Hušardzan (Newly found sites at the upstream of the river Aghavno), Hušardzan 6, Yerevan, 53-66 (in Armenian).

Gnuni A., Khačatryan G., Vardanyan G., Tadevosyan A. 2011: Hnagitakan usumnasirut'yunner LĞH K'ašataği šrjanum. Hnagitakan usumnasirut'yunnern Artsakhum 2005-2010 tt. (Archaeological studies in the region of Kashatagh, the Republic of Nagorno-Karabakh, Archaeological Studies in Artsakh in 2005-2010, Stepanakert), 41-70 (in Armenian).

Haxthausen A. 1857: Zakavkazskiy kray (Transcaucasian region), Saint-Petersburg (in Russian).

Ivanovski A. 1911: Po Zakavkazyu, Materiali po arkheologii Kavkaza (Along Transcaucasia, Materials on archaeology of the Caucasus,) vol. VIII, Moscow (in Russian). 
Kalantar A. 1925: K'are dari Hayastanum (Stone Age in Armenia), Nork 5-6, 207-232 (in Armenian).

Khačatryan T. 1975: Drevnyaya kultura Širaka (Ancient culture of Shirak), Yerevan (in Russian).

Khanzadyan E. 1969: Garni IV, Yerevan (in Armenian).

Khanzadyan E. 1979: Elar-Darani, Yerevan (in Armenian).

Khanzadyan E., Mkrtčyan K., Parsamyan E. 1973: Mec'amor, Yerevan (in Armenian).

Khnkikyan 0. 2002: Syuniq during Bronze and Iron Ages, Barrington.

Kušnareva K. 1996: Yužniy Kavkaz v IX-II tys. do n. è. (Southern Caucasus in the IXII millenniums BC.), S. Petersburg (in Russian).

Kvirkveliya O., Radilovski V. 1994: K voprosu ob etapakh issledovaniya arkheologičeskikh istočnikov. Metodologiya i metodika arkheologičeskih issledovaniy (Sbornik naučnikh trudov) (On the question of the stages of the study of archaeological sources. Methodology and methods of archaeological reconstructions (Collection of scientific papers), Novosibirsk, 10-12 (in Russian).

Lbova L. 1989: Arkheologičeskoye kartirovaniye: problemi i opit. Metodičeskiye problemi rekonstruktskiy $\mathrm{v}$ arkheologii $\mathrm{i}$ paleoekologii. (sbornik trudov). (Archaeological Mapping: Problems and Experiences, Methodological problems of reconstructions in archeology and paleoecology (collection of scientific papers), Novosibirsk, 181-190, (in Russian).

Mikaelyan G. 1968: Sevana lč‘ ‘ avazani kiklopyan amrotsnerə. Hayastani hnagitakan hušardzannerə, № 1 (Cyclopean fortresses of the Sevan Lake basin, Archaeological monuments of Armenia 1), Yerevan (in Armenian).

Narimanišvili G. 2009: Novie otkritiya $\vee$ Trialetskoy kulture. (New discoveries in Trialeti culture), Tbilisi (in Russian).

Piotrovski B.B. 1949: Arkheologiya Zakavkazya (Archaeology of Transcaucasia), Leningrad (in Russian).

Piotrovski B.B., Gyuzalyan L.T. 1933: Kreposti Armenii dourartskogo i urartskogo vremeni. Problemi istorii materialnoy kulturi (Fortresses of the Pre-Urartian and Urartian Armenia), Problems of History of Material Culture 5-6, S. Peterburg, 5159 (in Russian).

Rasulogli T. 1993: Tsiklopičeskie sooruženiya na territorii Azerbayjana. (Cyclopean constructions in the territory of Azerbaijan), Baku (in Russian).

Rienhold S. 2009: Zyklopische Festungen und Siedlungen mit symmetrischem Grundriss - Üeberlegungen zu einem überregionalen Phänomen der kaukasischen Spätbronzezeit, in: Der Schwarzmeerraum vom Äneolithikum bis in die 
Früheisenzeit (5000-500 v. Chr.): Kommunikationsebenen zwischen Kaukasus und Karpaten, Apakidze J., Govedarica B., Hänsel B. (Hrsg.), Prähistorische Archäologie in Südosteuropa 25, Rahden/Westf. 2009, 97-130.

Sanamyan H. 2010: Lč‘ašeni berdšeni kazmavorman p‘ulerə ev paštpanakan hamakargə, Hušardzan (Phases of the formation of the Lchashen fortress and its defensive system) 6, Yerevan, 45-52 (in Armenian).

Sardaryan S. 1967: Nakhnadaryan hasarakut'yunə Hayastanum (Primitive society in Armenia), Yerevan (in Armenian).

Sardaryan S. 2004: Hayastani k'ağak'akrt'ut'yan orran (Armenia as a cradle of civilization), Yerevan (in Armenian).

Sargsyan G., Gnuni A. Hakobyan A. 2014: Syunik'i arevelyan sahmanneri paštpanakan hamakargə $m$. $t^{t}$.a. II-I haz. (Defensive system of the eastern borders of Syunik in the II-I millenniums BC), Vem 1, 147-171 (in Armenian).

Simonyan H. 2013: Šengavit': šark'ayin bnakavayr te vağ k'ağak', Hušardzan (Shengavit: An ordinary settlement or an early city) 8, Yerevan, 3-75 (in Armenian).

Smith A., Badalyan R., Avetisyan P. 2009: The archaeology and geography of Ancient Transcaucasian societies 1: The foundations of research and regional survey in the Tsaghkahovit plain, Armenia, Chicago (Oriental Institute Publications 134).

Srvandzteants G. 1862-1863: Syunyats aškharh ev Šuši k'ağak', Arc'iv Vaspurakani 3 (Provinces of Syunik and the town of Shushi), 87-104 (in Armenian).

Tağiadian M. 1846: Kartsik' inč i Masis, (Opinion on Masis), Azgaser 38, 142-143 (in Armenian).

Tavernier J.-B. 1678: Six voyages of John Baptista Tavernier, London.

Trigger B. 1990: Monumental architecture: a thermodynamic explanation of symbolic behaviour, World Archaeology 22/2, 119-132 (in Russian).

Hayk Avetisyan

Yerevan State University, Republic of Armenia hykavetisyan@yahoo.com

Artak Gnuni

Yerevan State University, Republic of Armenia uruatry@rambler.ru 


\section{Levon Mkrtchyan}

Yerevan State University, Republic of Armenia levoncultur@gmail.com

Arsen Bobokhyan arsenbobokhyan@yahoo.com

Yerevan State University, Republic of Armenia

Fig. 1. Preliminary example of computer modeling. Air photo of Artanish peninsula fortress and its 3D/computer animation reconstruction
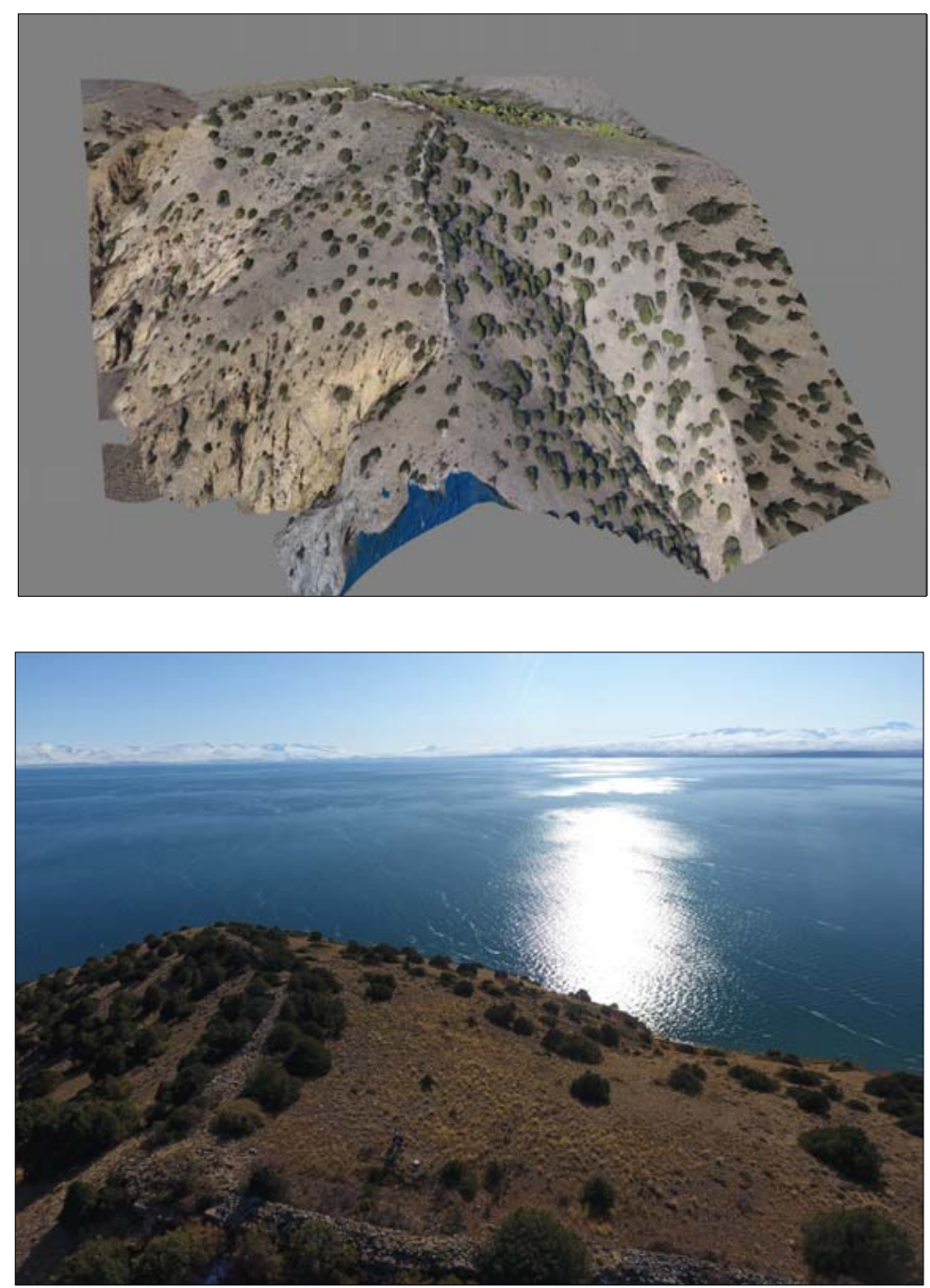


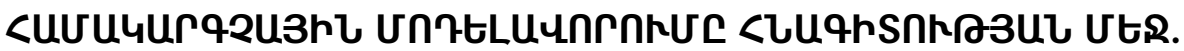

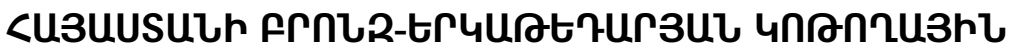 4unnh3s孔trh orhuuपnu
}

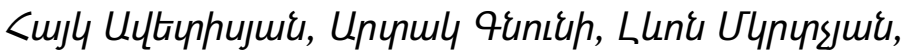 \\ Unutie fnpnpujue
}

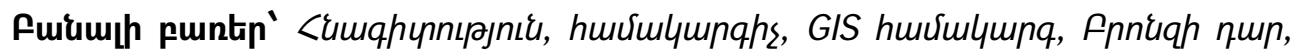

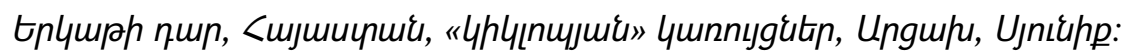

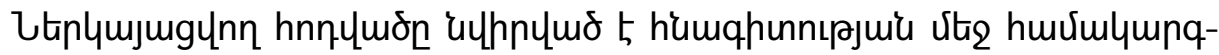

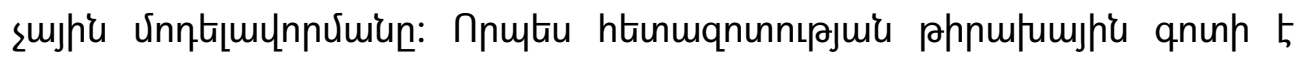

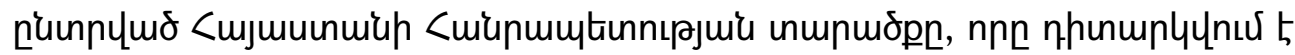

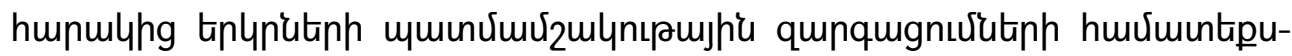

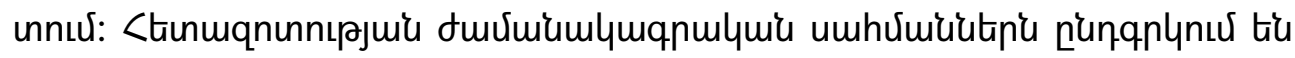

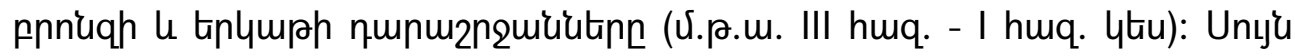

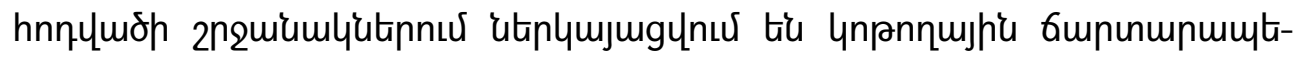

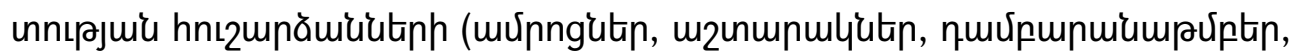



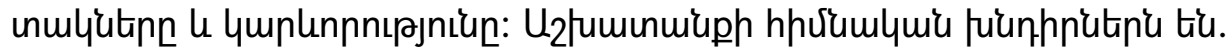

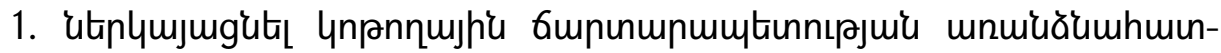
unıpnııüunn,

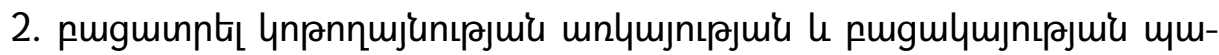



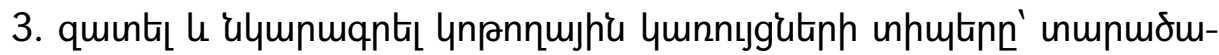

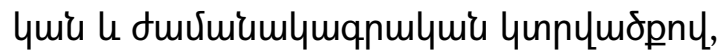

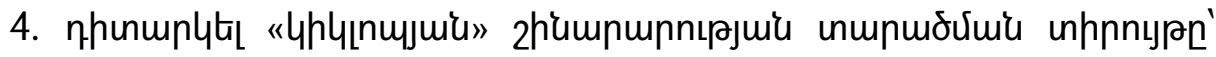

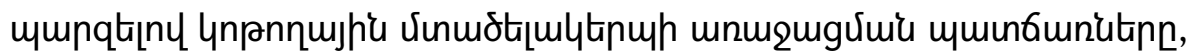

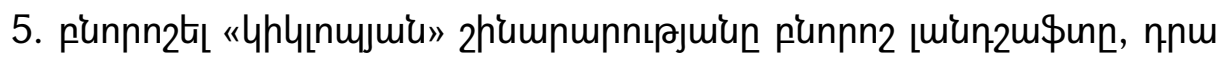

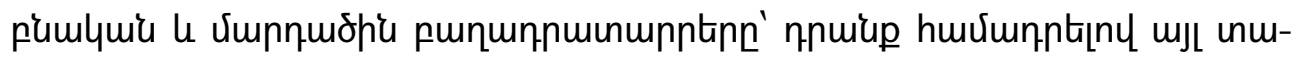
nuidputiph ophimulutiph htiun,

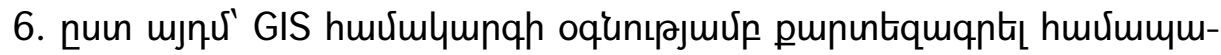
unuuutumü hnı2unămưütinn, 


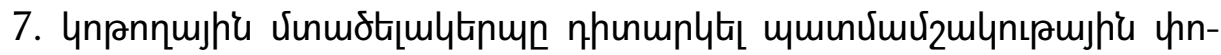

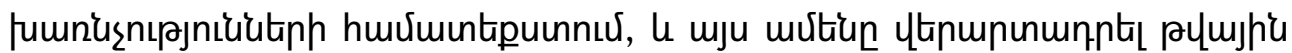
uhquiumjnnux: 